\title{
Translating Empire from Carthage to Rome
}

"The Roman people, destined to acquire wealth by conquest, and by the spoil of provinces; the Carthaginians, intent on the returns of merchandise, and the produce of commercial settlements, must have filled the streets of their several capitals with men of a different disposition and aspect. The Roman laid hold of his sword when he wished to be great, and the state found her armies prepared in the dwellings of her people. The Carthaginian retired to his counter on a similar project; and, when the state was alarmed, or had resolved on a war, lent of his profits to purchase an army abroad."1

So the Scottish philosopher Adam Ferguson summarised the fundamental differences between Romans and Carthaginians, and between their attitudes to empire, in 1767. This is a typical intervention in a conversation carried on throughout the long eighteenth century about the right way to think about Carthage and Rome, and, through them, about emerging European states. This conversation tended to emphasise the differences between the two cities, contrasting in particular their imperial practices - Roman territory with Carthaginian colonies, Roman conquest with Carthaginian trade, Rome's citizen militia with Carthage's reliance on mercenaries - and distinguishing between fundamentally different approaches to geopolitics: empires of the land and of empires of the sea. ${ }^{2}$

\footnotetext{
${ }^{1}$ Ferguson 1767, 291, quoted in Brooke forthcoming.

${ }^{2}$ Christopher Brooke has discussed this topic and the relevant texts in detail: Brooke forthcoming.
} 
This set of contrasts, which long framed and conditioned modern understandings of the two cities and of their empires, was based on ancient sources, and in particular the account found in the histories of Polybius. ${ }^{3}$ My contention here however, is that a narrow focus on the differences of detail between Carthage and Rome noted by contemporary commentators has led to a neglect of the larger parallels and inheritances they underlined, and in so doing so has missed the extent to which Rome inherited Carthaginian practices and ideologies of empire. My aim here is not to establish whether the two cities really were fundamentally similar or different in this respect: like 'continuity and change', this is a yes/yes question, and it is in any case now widely accepted that they both exercised significant power over land and sea, at least from the fourth century BCE. ${ }^{4}$ Instead, I want first to explore the contrast between modern and ancient perceptions of the relationship between the two empires in more detail, and then to investigate some specific examples of imperial practices and ideologies that might have transferred to Rome along with Carthage's territory and subjects.

\section{Contrasting Models}

The ancient struggle between Rome and Carthage was born again in the early modern period, as Europe's intellectual elite constructed - and occasionally deconstructed - a series of oppositions between the ancient cities, mapping them explicitly onto modern

\footnotetext{
${ }^{3}$ Vlassopoulos 2010, 31-33 on the importance of ancient history in eighteenth century intellectual culture.

${ }^{4}$ Maritime Rome: e.g. Steinby 2014, 34-40. Territorial Carthage: e.g. Quinn 2012/2013 [2014], 25, with references.
} 
states. ${ }^{5}$ In the seventeenth century the standard modern comparison was between Britain, described by Milton in 1660 as aspiring to be "another Rome in the West", 6 and its great competitor for the control of international trade, the Dutch United Provinces, which were popularly associated with Phoenician Carthage. Military disputes between the two were often described in terms of the Punic Wars, most famously in 1673, when the Earl of Shaftesbury declared in Parliament Delenda est Carthago, "Carthage must be destroyed". ${ }^{7}$ By the mid-1670s, however, the Dutch star was in decline, England was the world's leading maritime power, and it was the French who presented the greatest threat to their interests. The scholarly opposition between Carthage and Rome thrived on the military friction between England and France throughout the eighteenth century. ${ }^{8}$

One great English champion of the Carthaginians in this period was Edward Wortley Montagu, described succinctly in the Oxford Dictionary of National Biography as a “traveller and criminal". He was also a soldier, an Arabic scholar, and a member of parliament. His Reflections on the Rise and Fall of the Antient Republics Adapted to the Present State of Great Britain was first published in 1759 during the Seven Years War between England and France, and it was popular, going through four editions by 1778. Montagu makes the four-way equation between Carthage, Rome, Britain, and France crystal clear:

\footnotetext{
${ }^{5}$ This section draws on a chapter on this topic in Quinn forthcoming.

${ }^{6}$ Milton 2013, 484-485.

${ }^{7}$ Grey 1763, II, p.2: 5 February 1673.

${ }^{8}$ Vance $2000,216-217$.
} 
Of all the free states whose memory is preserved to us in history, Carthage bears the nearest resemblance to Britain, both in her commerce, opulence, sovereignty of the sea, and her method of carrying on her land-wars by foreign mercenaries. If to these we add the vicinity of the Carthaginians to the Romans, the most formidable and most rapacious people at that time in Europe, and the specific difference, as I may term it, of the respective military force of each nation, the situation of Carthage with respect to Rome, seems greatly analogous to that of Britain with respect to France, at least for this last century. ${ }^{9}$

Britain, he says, should learn from the failures of Carthage, a city that relied too much on mercenaries, "[s]trangers to that heart-felt affection, that enthusiastic love of their country, which warms the heart of free citizens, and fires them with the glorious emulation of fighting to the last drop of blood in defence of their common mother". ${ }^{10}$

The comparison and contrast was also popular in France. In 1734, in a work published in English as The Causes of the Grandeur and Declension of the Romans, Montesquieu argued that "Carthage, in warring with all its riches against the poverty of Rome, had a disadvantage in this very circumstance; for gold and silver may be exhausted, but virtue, perseverance, strength and poverty are inexhaustible". ${ }^{11}$ For him this was one part of a broader critique of Rome as an appropriate model for

\footnotetext{
${ }^{9}$ Montagu 1759, 161.

${ }^{10}$ Montagu 1759, 174; cf. 162-3, 169, 170, 172-3, 179, 198-9.

${ }^{11}$ Montesquieu 1777, vol. 3, 21. The French title is Considérations sur les causes de la grandeur des Romains et de leur décadence.
} 
European states, including France, ${ }^{12}$ but others exploited the ancient contrast for more straightforwardly nationalist purposes: the rhetoric of Carthage's destruction came full circle in 1798, when Paul Gauran, a deputy in the post-revolutionary Conseil de Cinq Cents, advocated war on the English government, "oppresseur de toutes les Nations", by evoking the traditional cry, "Que Carthage soit détruite!"13

This is all quite different from the way that contemporary scholars of the Hellenistic period framed the relationship between Carthage and Rome, as similar cities with similar histories. Eratosthenes of Cyrene, chief librarian at Alexandria in the third century BCE, compared the political conduct of these two barbarian civilizations: "not only are many of the Greeks bad, but many of the Barbarians are refined, Indians and Arians, for example, and, further, Romans and Carthaginians, who carry on their governments so admirably" (Strabo 1.4.9), while earlier in the same century Timaeus of Tauromenium had even claimed that Rome was founded in the same year as Carthage (814/3 BCE).${ }^{14}$ Our best source on this topic, as Montagu and Montesquieu were well aware, is the Greek historian Polybius of Megalopolis, writing in Rome in the second century BCE. However, while Polybius' account details differences between Carthage and Rome, these are usually taken out of context by later scholars,

\footnotetext{
${ }^{12}$ Brooke forthcoming, with examples of the subversion of the basic oppositional model by, among others, Pierre-Daniel Huet, Voltaire, and Adam Smith. ${ }^{13}$ Gazette national de France 1798, p. 715. On the sentiment of "perfide Albion" in France, see Schmidt 1953 and Bernal 1987, 341-2, along with the contemporary report at Rawlinson 1889, 62.

${ }^{14}$ BNJ 566 F 60 (= Dion. Hal. Ant. Rom. 1.74.1), with Feeney 2007, 92-95.
} 
and therefore misunderstood: his basic point is that Carthage and Rome are at different points on a very similar political and imperial trajectory.

\section{Polybius and the Succession of Empires}

Polybius took the view that the good governance Eratosthenes observed at Carthage and Rome was a result of their mixed constitutions, a form of politeia restricted for him to just three cities:

The constitution of the Carthaginians seems to me to have been well framed from the first as regards its general distinctions. For they had kings, and the gerontion was an aristocratic body, and the multitude were masters of matters appropriate to them, and the way in which the whole system worked was very similar in general to that of the Romans and the Spartans (Polyb. 6.51.1-2). ${ }^{15}$

Furthermore, as he explains in an extended comparison in Book 6 of his Histories, Carthage and Rome were more similar to each other than either was to Sparta, because their constitutions allowed them to extend their power well beyond their own confines, while the Spartan politeia - and in particular the Spartans' use of crops and iron bars for money - was unsuited to the exercise of power over others (Polyb. 6.49$50)$.

Nonetheless, despite their fundamental political and imperial parallels, Carthage and Rome were at different stages in the journey all states make through growth and then decline, and so by the time of the Second Punic War:

\footnotetext{
${ }^{15}$ See further on the benefits of the mixed constitution Polyb. 6.3.7, with 6.10.6-11, and on Sparta, Carthage and Rome, 6.47.9.
} 
the Carthaginian constitution had deteriorated, and the Roman one improved...the demos had already acquired the greatest power in decisionmaking among the Carthaginians, while among the Romans the senate was the driving force. Since in the one case the many took decisions, and in the other the best, the decisions of the Romans on public matters were better. As a result, although they met very difficult obstacles, through good decisionmaking they finally conquered the Carthaginians in the war (Polyb. 6.51.3, 68).

This passage lies directly behind a remark made by Montesquieu that "at Rome, which was governed by laws, the people entrusted the senate with the management of affairs; but in Carthage, which was governed by fraud and dissoluteness, the people would themselves transact all things", ${ }^{16}$ and Polybius goes on over the next chapters to examine a number of the differences "of detail" (ta kata meros) between the states that led to Roman victory over Hannibal which were seized upon by eighteenth century writers, despite the fact that Polybius was explicitly describing minor differences between very similar states at different stages of their political and imperial development. Polybius contrasts Rome's extensive military training on land with Carthage's focus on preparation for naval campaigns, and explains Carthage's neglect of the former as due to their employment of foreign mercenaries: for him Rome's reliance on the bravery of its own citizens helped ensure its eventual success on both land and sea (Polyb. 6.52-55; cf. 1.65.7 and 3.109.6-8). He also notes the cities' distinctive laws and customs relating to the acquisition of wealth - in Carthage

\footnotetext{
${ }^{16}$ Montesquieu 1777, vol. 3, 21.
} 
"nothing is shameful that leads to profit" - and the centrality of religion to the Roman state, "in order to gratify the common people" (Polyb. 6.56.2, 9). At the same time, however, he constructs a broader conceptual framework largely ignored by later writers, not only of similar governance within the two cities, and of a similar political trajectory, but also of a similar imperial trajectory, and even of direct imperial inheritance.

Polybius concludes his comparison between Carthage and Rome at 6.57 with a reiteration of the inevitability of decline, and - though neither state is explicitly named - a prediction that Rome will suffer the same democratic fate he has already ascribed to Carthage in similar terms at 6.51: when a state has reached the heights of prosperity and power, he says, its wealth leads its citizens into extravagance and rivalry, in particular for political office, which provoke a deterioration:

And the people will be taken to be the authors of this change, when from some they seem to be suffering injustices as a result of greed, and by others they are filled with flattery out of love of office. For then, enraged, and following their passions, they will refuse any longer to obey, and they will demand not equality with their leaders, but all or the greatest part themselves (Polyb. 6.57.7-8).

The logic of Polybius' argument suggests furthermore that the same principles and dynamic apply to empires as to constitutions, with Rome following the same path as Carthage, to the same eventual end. At the beginning of his Histories, Polybius describes the limitations of the three pre-Roman imperial powers in the East. The Persians ruled in Asia but failed in their attempts to extend their power further; the 
Spartans managed no more than a brief rule over Greece; and even the Macedonians, who conquered Europe from the Adriatic to the Danube, and overthrew the Persians in Asia,

although they seemed peerless both territorially and politically, still left the larger part of the inhabited world outside it. For they never tried to contend for Sicily, Sardinia, or Libya at all, and in Europe they were, to speak plainly, ignorant of the most warlike of the western peoples. While the Romans have subjected to themselves not some part but practically the whole of the inhabited world. (Polyb. 1.2.5-7).

In order to do so, he implies, the Romans had to look to Carthage instead as an example, saying just a few chapters later that in 264 "the Carthaginians had not only subjected Libya, but many parts of Iberia as well, and that they had also taken possession of all the islands in the Sardinian and Tyrrhenian seas" and that beyond Syracuse and Messene "they were in control of almost all the rest of Sicily" (Polyb. 1.10.5, 8). Over the three Punic wars that followed, the Romans inherited all those territorial possessions of Carthage, and Polybius' language continues to emphasise the specificity of that inheritance: in 218, the Carthaginians controlled north Africa from the altars of Philaenus to the pillars of Heracles (Polyb. 3.39.2); in 146, Scipio Aemilianus brought Africa from the altars of Philaenus to the pillars of Heracles under Roman power (Polyb. 10.40.7).

In practical terms, this is a simple acquisition of territory. But Polybius also presents episodes book-ending these Punic wars that link the two empires more closely, suggesting that the Romans inherited more from Carthage than land. The first of these is of course the famous story about a Carthaginian decked vessel that was captured in 
a battle in the straits of Sicily in 264 and used as a model for a new Roman naval fleet, which eventually turned the course of the war Rome's way (Polyb. 1.20), an episode treated at length by Tom Biggs elsewhere in this volume. The second comes at the end of the third Punic War, when Polybius himself stands beside Scipio as Carthage burns, and "turning to me at once and grasping my hand, Scipio said 'A glorious moment, Polybius, but I have a dread foreboding that some day the same doom will be pronounced upon my own country."” (Polyb. 38.21.1; cf. Diod. Sic. 32.24 and App. Pun. 132). This presents an acknowledgement on the part of a Roman that the two cities were travelling the same imperial path , and according to Polybius, Scipio is right to be concerned: "Judgments concerning either the victors or the vanquished which are based on nothing more than the outcome of battles cannot possibly be final; for what have appeared to be the most striking successes have often, if they are not rightly used, brought the most overwhelming disasters in their train." (3.4.4-5). On his account, then, empires follow a similar dynamic and pathway to constitutions, and Carthaginian empire was not only a forerunner to Rome in the west, just as the Macedonian kingdoms were in the East, but a source of practical and political lessons, a phenomenon now known as 'imperial transfer'.

\section{Imperial Co-operation and Transfer}

Although there have been endless studies of empires in terms of their conflicts, many fewer have dealt with their interactions with and even reliance on each other to achieve their own imperial goals. Recently, however, several conferences and publications have focused on such encounters between empires, tackling the question of how $19^{\text {th }}$ and $20^{\text {th }}$ century imperial states co-operated and collaborated with each 
other, and learnt imperial technologies and techniques from each other. ${ }^{17}$ The term "imperial transfer" is the most common one now used to describe "the way empires designed their policies by referring to their imperial predecessors, [which] provided a reliable method to prevent 'the provincialism of each empire prevailing' on the one hand, and to legitimize imperial policies on the other". ${ }^{18}$ And these studies have concluded that the "circulation and transfers of specific knowledge orders and power practices were crucial for the implementation as well as the durability of empires."19

Is this also true of the ancient world, and in particular of the two empires under consideration here? Although Robert Palmer has reconstructed the history of cultural and commercial contact between the two cities in his account of Rome and Carthage at Peace, there has been little focus on active collaboration and transfer in the sphere of empire. ${ }^{20}$ I want to suggest, however, that the Roman conquest of the west did involve imperial inheritance, imperial co-operation, and imperial transfer.

Examples of practical co-operation and collaboration between Carthage and Rome in the interests of their respective empires can easily be found: as far back as the sixth century, the famous treaty made between Rome and Carthage binds them at least in theory to respect each other's spheres of hegemony, and to control their own merchants to protect the commercial interests of the other, and also suggests that

17 E.g. Aust and Schönpflug 2007; Leonhard and Hirschhausen 2011; Barth and Cvetkovski 2015.

${ }^{18}$ Barth and Cvetkovski 2015, 9, quoting Hart 2008, 16.

${ }^{19}$ Barth and Cvetkovski 2015, 7.

20 Palmer 1997. 
Carthage might actively aid Rome's imperial expansion: if they take a city of Latins not subject to Rome, they should deliver that city up to Rome (Polyb. 3.22.12; cf. Polyb. 3.24.5 for a fourth century renewal). Those provisions were probably largely theoretical, but during Rome's war against Pyrrhus of Epirus, the Carthaginians provided naval transport for Roman troops, destroyed Pyrrhus' supplies, and intercepted his fleet on its way to Italy. ${ }^{21}$ Rome repaid these favours during the Mercenary War by returning many Carthaginian prisoners, forbidding its merchants to trade with the rebels, and refusing offers of defection from Sardinia and Utica (Polyb. $1.83)$.

As for imperial transfer, the case that Rome learnt a lot from the Greek East in the process of conquest there is familiar, with the role played in that education by existing eastern empires most vividly illustrated in the early second century when the Roman general T. Quinctius Flamininus adopted the rhetoric of Greek freedom and the iconography of Hellenistic kingship. ${ }^{22}$ But how far did Rome treat Carthage as a source of imperial models, methods and technologies?

${ }^{21}$ Diod. Sic. 22.7.5, with Miles 2010, 415, n.30, and Plut. Vit. Pyrrh. 24.1. ${ }^{22}$ Gruen 1984 is a classic account; on Flamininus' rhetoric see Polyb. 18.46.5 with Walsh 1996, and on his use of Hellenistic imagery, practices and techniques on the gold staters that he struck in Greece c. 196 see most recently Thonemann 2015, 169170, with bibliography, and the reservation that this unusual coinage represented the "the road not taken by Rome in the eastern Mediterranean in the last two centuries BC" (170). 
The poverty of the evidence for this topic cannot be over-estimated, and Sandrine Crouzet has demonstrated with stinging clarity how much modern scholarship has relied on assumed parallels with Roman practices and categories to interpret what little evidence there is for Carthaginian ones. ${ }^{23}$ An interest in acquiring technical expertise from Carthage in the pursuit of empire is however suggested by Polybius' story of the transfer of naval technology during the First Punic War, and by the senate's resolution after the Third Punic War to have the works of the Carthaginian agronomist Mago translated into Latin, an aid no doubt in the agricultural exploitation of their new lands in Mago's own Africa as well as in Italy (Plin. HN 18.22-23). And I think we can go further. The rest of this paper will survey a series of similarities between Carthage and Rome in the ways they treated their subjects, managed military recruitment, thought about borders, formulated treaties, and organised taxation. Some are most likely to be simple coincidences; others suggest, and sometimes explicitly demonstrate, the active Roman exploitation of Carthaginian ideas and technologies.

\section{Strategies of Subjection}

The chance survival of a remarkable document contains a self-presentation of late Carthaginian empire. In 215 BCE, a treaty was concluded between Hannibal and a representative of Philip II of Macedon. Livy tells us that this document was retrieved by Roman naval officers from a Macedonian ship as Philip's ambassador Xenophanes returned from his meeting with Hannibal (Livy 23.33-34); the text itself is preserved in a fragmentary book of Polybius (7.9). It is of course possible under these circumstances that the document is not genuine, but it must have been plausible

\footnotetext{
${ }^{23}$ Crouzet 2003.
} 
enough to convince contemporaries, including Polybius - and in fact there are good reasons to consider it authentic: the format, a covenant that begins with a long invocation of a variety of gods, is distinctly near eastern, and aspects of the language used strongly suggest that the Greek is a translation from Punic. ${ }^{24}$ This translation would have been made in Hannibal's camp, and so this document gives us a more than usually direct window onto Carthage's own perception and presentation of its empire in the later third century, including the fullest list we possess of Carthage's associates in that empire. In this treaty, Philip II and his allies agree to protect the Carthaginians - the lords (kurioi) - and Hannibal the general, and those with him, and all subordinate (huparchoi) to the Carthaginians, who use the same laws, likewise the Uticans, and the cities and peoples who are subject (hupékoa) to the Carthaginians, and our soldiers and allies and cities and peoples in Italy, Keltia, and Liguria, with whom we are in friendship or with whomsoever in this country we may hereafter enter into friendship and alliance. (Polyb. 7.9.5) $)^{25}$

Modern analyses of the categories listed here have often suggested that they mirror juridical categories found at Rome - that the term kurioi denotes citizenship optimo

\footnotetext{
${ }^{24}$ Bickerman 1944; Bickerman 1952; Barré 1983.

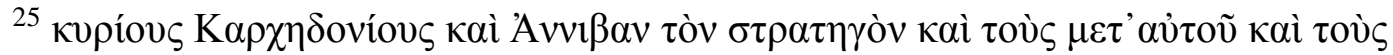

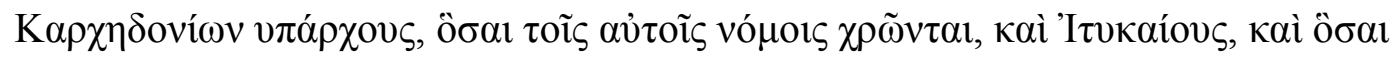

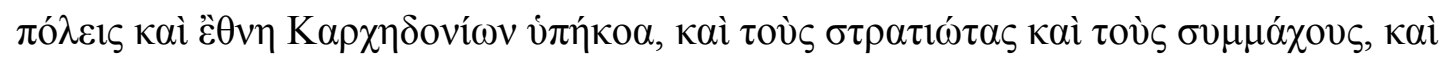

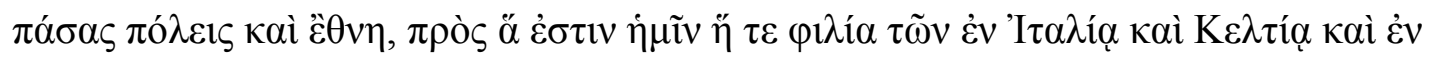

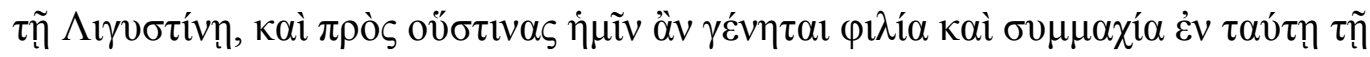

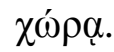


iure, for instance, ${ }^{26}$ or that the huparchoi, who share nomoi with the Carthaginians, mapped on to the Roman category of the 'Latin name'. ${ }^{27}$ These suggestions have been comprehensively refuted in recent years, and I want to draw attention instead to the way in which a whole variety of Carthage's allies, dependents and subjects are arranged in a hierarchical structure which would have discouraged them from making common cause, and may well have cut across traditional local power structures and boundaries.

A similar approach can be found in Rome's descriptions of its own allies: the earliest direct evidence is the lex de repetundis, our first extant Roman law on bronze (c.123/2 $\mathrm{BCE}$ ), which begins by listing the people who can use this legislation against extortion practised by Romans: "[...anyone of the allies] either of the Latin name or of external nations, or anyone in the discretion, sway, power or friendship [of the Roman people]". ${ }^{28}$ Here again subjects are divided into a complex hierarchy under one supreme commander state, and the document identifies a specific inner circle of allies, in this case of the Latin name, a group who shared a number of rights with Roman citizens, along with the burdens and booty of war. Divide-and-rule is not of

${ }^{26}$ Bickerman 1944, 97, with earlier bibliography; contra, see HCP ad loc and ad 10.16.1.

${ }^{27}$ See Crouzet 2003, 656-659, for the long history of this hypothesis, from Mommsen to Walbank, and for its many inadequacies.

28 [--- quoi socio no]minisve Latini exterarumve nationum, quoive in arbitratu dicione potestate amicitiav[e populi Romanei ---]. For the restorations and further commentary, see Lintott 1992 ad loc., and (with minor variations) Roman Statutes ad loc. 
course an unusual imperial technique, however, and the similarities here may well be coincidental.

\section{Military Recruitment}

The same is probably true of military recruitment. The Roman and Carthaginian armies are usually seen - in line with one of Polybius' "differences of detail" - as fundamentally dissimilar operations, one based on citizen soldiers, the other on foreign mercenaries. The ancient sources, however, record a similar range of recruitment strategies in the two cities.

Diodorus provides a snapshot of Carthaginian strategy in c. 397, when the city's generals were preparing for an assault on Sicily. He explains that they sent representatives "with large sums of money" to levy mercenaries (xenologein) from the Balearics and Iberia, while they themselves canvassed Libya registering (katagraphontes) soldiers from among the Libyans, Phoenicians and (presumably Carthaginian) citizens; they also summoned (metepemponto) troops from allied peoples and kings in Africa, including the Nomades, Marausii and peoples living in the area of Cyrene, while hiring them (misthōsamenoi) in Italy (Diod. Sic. 13.80.2-3). Carthage's forces are recruited here in three distinct ways: Italian, Spanish and Balearic soldiers are hired as mercenaries, African allies send auxiliaries, and there is also a registration of men from among the Libyan and Phoenician populations, including Carthage itself. 
Other sources appear to confirm that Carthage's allies were liable to having troops summoned from them, ${ }^{29}$ and that subject peoples were required to provide troops from the fifth century in Libya, and the third in Iberia. ${ }^{30}$ This basic three-way division between hired mercenaries, paid auxiliaries summoned from allies, and conscript troops drawn from the local Libyan and Phoenician population also fits in with the list of the troops that Hannibal left with Hasdrubal in Spain in 218, where the number of Libyans and 'Libyphoenician' cavalry (450) is given separately from that of African Nomades made up of Massylians and Masaisylians and Makkoians and Maurusians (1800), and separately again from the 300 Iberian Ilergetes - suggesting that the division between conscripts, auxiliaries, and mercenaries was a bureaucratic reality in his army rather than simply Diodorus' interpretation (Polyb. 3.33.15). ${ }^{31}$

This tripartite approach is also found in Roman recruitment strategies. Beyond the immediate citizen body, Rome's military conscription of their Italian allies was organized from at least $225 \mathrm{BCE}$ through the formula togatorum lists, ${ }^{32}$ and the subjects they inherited from Carthage in Sicily and Spain seem to have been required to provide troops and in some cases ships, just as they were under the previous

\footnotetext{
${ }^{29}$ E.g. Diod. Sic. 13.80.3; 14.54.5 (Libyans and Iberians, 396); 16.67.1 (“friendly representations" to Sicilian allies in the face of impending war, 345/4); 19.106.5 (Sicilians, 311); 20.18 .3 (“Libyan allies”, perhaps a rather loose designation, 310). ${ }^{30}$ Moscati 1972, 692, with references; Crouzet 2003, 685-686, on Libyan subjects, with Diod. Sic. 13.54.1 and 13.80.3.

${ }^{31}$ Cf. the discussion of this passage at Crouzet 2003, 667.

${ }^{32}$ Polyb. 2.23.9, cf. 2.24 and 6.21.4; Roman Statutes 2 (lex agraria) 11. 21 and 50 for the phrase formula togatorum; Prag 2011a, 19; Kent 2012.
} 
Carthaginian regime. ${ }^{33}$ The Romans also recruited foreign auxiliary troops and there is a reasonable amount of evidence that they hired mercenaries overseas from the late third century, directly and indirectly, despite the invective against mercenaries in public discourse. ${ }^{34}$ Curiously, however, there is no direct evidence for the conscription of Libyans after the fall of Carthage, even during the Jugurthine War, suggesting that by the mid-second century at least, the Romans were not simply adopting existing practices in the areas they inherited from Carthage. ${ }^{35}$ More generally, the use of conscription, auxiliaries and mercenaries is not unusual in the ancient world, and this example may speak again more to basic similarities between the two states than to direct imperial transfer.

\section{Imperial Space}

A more suggestive example concerns the two cities' shared conceptions of imperial territory and its limits, where Rome and Carthage are on the same side of a Hellenistic debate. It is well known that place played little role in conceptions of Roman power during the late Republic, and that correspondingly little attention is paid to the definition and construction of imperial borders in that period; indeed the only real

\footnotetext{
${ }^{33}$ Prag 2011a, 17-22 for regular and irregular levies in the provinces, with references. ${ }^{34}$ Prag 2011b, 107-108, esp. n. 27.

${ }^{35}$ A lack of recruitment in Africa would correspond with other evidence for the slow growth of Roman interest in its new African "province" in the later second century (Quinn 2004).
} 
question is over the relevance of either concept even in the Imperial period. ${ }^{36}$ There are no geographical conceptions involved in the lex de repetundis discussed above, and in particular no boundaries to Roman empire or territory are mentioned, only peoples, cities, and nations within it, described in terms of their legal status (as established by Romans) and their relationship to Rome, just as in Hannibal's treaty of 215.

Imperial borders first appear in Roman documentation in the so-called lex de provinciis praetoriis of c.100 $\mathrm{BCE}$, where the Roman officer who holds Macedonia as his province is directed to establish the boundaries of the taxation of the Chersonese as quickly as possible (Roman Statutes 12 Cnidus IV, 28-30). In the same law there is a reference to an earlier lex Porcia, according to which a Roman magistrate cannot travel outside his province, except by senatorial decree, other than for transit or reasons of state, and he is to restrain his staff from doing the same (Roman Statutes 12 Cnidus III, 4-15). Both imply a notion of geographical boundaries to provinces, but still not to the empire as a whole.

Where clear terrestrial boundaries around, rather than within, the Roman empire are found, they are other people's. The limit of Roman power in Africa after the destruction of Carthage, for instance, is marked by a ditch which Pliny says was agreed between Scipio Aemilianus and the kings, and which later inscriptions call

\footnotetext{
${ }^{36}$ Purcell 1990; Whittaker 2004; Richardson 2008, 186-187. For the more general point that "cartographic" space was less important than the "hodological" routes through it in ancient conceptions, the classic text is Janni 1984, and see more recently Purves 2010, 118-158.
} 
fossa regia - the royal ditch (Plin. HN 5.25; CIL 8.25967). Since we know that bounded territory was a concern of the Numidian kings, who argued successfully in 201 to keep the territory that their fathers possessed as a limit to Carthaginian power, it seems likely that the fossa regia was originally a project of the Numidian kings, not of Scipio. ${ }^{37}$ They might well have thought they had much to gain from a clear (and from their point of view generous) boundary to the territory that Rome would allow them to exploit; the Romans in turn accepted a convenient external border, beyond which control and certainly tax collection would be an awkward proposition. ${ }^{38}$

It is not clear when this boundless conception of Roman empire arose, although Polybius suggests that Roman ambitions for "universal rule and dominion" were only fully formulated after their victory in the Hannibalic war (Polyb. 1.3.6; cf. 3.2.6). Whether or not he is right about the dating and the context, could the ideology itself have been borrowed from Carthage? This may seem on the face of it an unlikely suggestion, given the familiar assertion that a frontier was established between the Syracusan and Carthaginian realms in Sicily in the fourth century, at the Halykos river. I want to suggest here though that that is a misinterpretation of what we are told about the relevant treaties, and that in fact both the Carthaginians and Romans, despite their undoubted territorial interests and exploitation, thought - and acted - in terms of rimless, universal empire.

${ }^{37}$ Quinn 2004, 1598-1599. It has even been suggested that the existence of the fossa regia contributed to the formation of the Roman conception of provincial boundaries (Crawford 1990, 107 n. 68).

${ }^{38}$ For attempts to map out its route, see Di Vita-Évrard 1985 and Ferchiou 1998. 
Two treaties are relevant to the problem of the Halykos river. In the 370s, the victorious Carthaginians concluded their third war with Dionysius on the terms that he should pay a war indemnity, and that both sides should hold what they possessed, "the only exception being that the Carthaginians received the city of the Selinuntians and its land (chora), as well as that [land] of Akragas as far as the river called Halykos" (Diod. Sic. 15.17.5). There is disagreement as to the modern identity of this river ${ }^{39}$ all that matters for our purposes is that it cuts through Agrigentine territory and is used here simply to clarify how much of that territory is now transferred to Carthage. It therefore forms a border between those two parcels of land, not, as is often claimed, between two empires or spheres of hegemony on the island. ${ }^{40}$ Of course, this could never have been the case, since if a river bisected Sicily, it would be two islands rather than one. And although scholars have attempted to continue the boundary line north, either along the Himera river or with reference to the city of Himera itself, there is no evidence that this was done by the ancient protagonists. ${ }^{41}$

${ }^{39}$ See Stylianou 1998 ad loc. for the debates and bibliography.

${ }^{40}$ Cf. Mazzarino 1947, 47-48 (“Già a conclusione di questa guerra...fu chiarito stabilmente che il confine tra le due epicrazie era al fiume Halykos"); Anello 1986, 169 ("si fissa un confine preciso tra i rispettivi territori”); Caven 1990, 200 and 221; Vincenzo 2013, 396 ("the boundary of Carthaginian territory on Sicily were [was?] defined for the first time: the river Halykos formed the border"), with 19-26. Cf. Bondì 2014, 64, on the creation of a fortified frontier at the Halykos, and BNP s.v. Halycus ("the demarcation line between the two spheres of control").

${ }^{41}$ E.g. Mazzarino 1947, 48; Caven 1990, 200; Stylianou 1998, 208. Compare the treaty briefly proposed by Hieronymus of Syracuse to Carthage in 215, in which the 
However, a river plays a more decisive role in a treaty made with Timoleon in 338 after the ruler of Syracuse has defeated the Carthaginians:

When the Carthaginians sent envoys and pleaded with him urgently, he granted them peace on the terms that all the Greek cities should be free, that the river Lykos should be the boundary of their respective territories, and that the Carthaginians might not give aid to the tyrants who were at war with Syracuse (Diod. Sic. 16.82).

Here the river Lykos - which may or may not be the same as the Halykos of the previous agreement - is proposed by Timoleon as a boundary between Carthage and Syracuse rather than individual towns. Nonetheless, this is still a purely regional phenomenon. The agreement is about distributing territory and taxation on the southern coast of Sicily: the river did not divide Greek and Sicilian interests on the island as a whole, drawing a line between geopolitical spheres. After all, as noted above, in the period leading up to the first Punic War, Polybius suggests that the Romans understood Carthage to control almost all of Sicily beyond Syracuse and Messene (Polyb. 1.10.8).

At the same time, the mouth of the river would have marked an important boundary point to passing shipping, denoting for sailors a point from which the coast was subject to Carthaginian rule and rules. This approach to empire is characteristic of Carthage's treaties, where there is a general pattern of using natural and manmade features as way-markers to indicate maritime routes and rules, not to mark terrestrial

river Himera alone was to be the boundary (horos) between their eparchies if the Romans were driven from Sicily: Polyb. 7.4.1-2; Livy 24.6.7. 
frontiers. One example on the African coast is the "beautiful promontory" mentioned in the treaties between Carthage and Rome as a point beyond which there are restrictions on Roman shipping (Polyb. 3.22-24). Another is the altars of the Philaeni mentioned above, which have sometimes been supposed to mark a territorial border between Carthage and Cyrene, although no southern end to such a boundary is ever mentioned in our sources; I have argued elsewhere that these low hills instead marked a point on the coast after which the ports and their tax rights were subject to Carthage. ${ }^{42}$ Whatever the precise location of the "beautiful promontory", these two points on the African coast would have captured between them the rich lands of Byzacena and the Emporia, the area delivering to Carthage one talent a day in 193 BCE. And such maritime boundary markers are a feature not only of Carthage's treaties with Rome, but of those struck by Rome with other western powers as well (Appian Sam. 7.1-2, on an old treaty between Rome and Tarentum; Polyb. 2.12.3 and Appian Ill. 7 on the treaty between Rome and Pinnes of Illyria).

Two other brief passages might suggest a notion of a border to Carthaginian empire, but neither is convincing. Firstly, Appian claims that in 201, at the end of the Hannibalic War, the Phoenicians were ordered by Scipio to evacuate all garrisons, towns and land beyond "the Phoenician trenches" (App. Pun. 54, 59). Even if this is correct - it contradicts to some extent Polybius' account of the same arrangements, where Massinissa is awarded his "ancestral lands" within boundaries that would be determined at a later date (Polyb. 15.18.5; cf. Livy 30.37.2; Cass. Dio 17.82) - there is no reason to think that these trenches were considered boundary markers by the Phoenicians: indeed, the fact that they have to withdraw from beyond them suggests

${ }^{42}$ Quinn 2014. 
in fact that they were not. And the plural is telling: whatever these are, they are not a continuous land barrier, but perhaps either temporary military installations, or some form of customs point like the later Roman limes. ${ }^{43}$

Secondly, Phlegon of Tralleis, one of Hadrian's freedmen, says that Eumachos of Naples, a historian of Hannibal perhaps writing as early as the second century BCE, wrote in his "Geographical Description" that when the Carthaginians dug a trench around their own eparchia - the word is of course Phlegon's, we do not know exactly how Eumachos described the incident - they found two giant withered corpses buried in coffins (BNJ $178 \mathrm{~F} 2)$. Whether or not this ditch is the same as the trenches mentioned by Appian, it seems plausible that it was a temporary military structure, perhaps excavated, as Duane Roller suggests, "when the Carthaginians were preparing for the Roman attack late in the Second Punic War". ${ }^{44}$ No date is assigned to the story, however, and it is also possible that this is a version of the city's early history: according to Justin's epitome of Pompeius Trogus, mysterious objects were repeatedly dug up as the foundations for Carthage were being laid (Just. Epit. 18.5.1516).

\footnotetext{
${ }^{43}$ Lancel suggests that they would have been similar to the fortress-defences found at Ras el-Drek on the tip of Cap Bon, and apparently in use c.400-146 (Lancel 1995, 265). Whittaker proposes that they were an attempt to control the movements of the more nomadic populations (Whittaker 1978a, 339). For Walsh they are "probably the invention of a late annalist"; he points out that not to mention them is an "incredible omission" at Polyb. 15.18 (Walsh 1965, 156).

${ }^{44}$ BNJ ad loc.
} 
As with Rome, where limited terrestrial boundaries to Carthaginian power are found, they are imposed by others: by Timoleon in Sicily in 338, and by the Romans, on behalf of the Numidians, after the second Punic War. In fact, what we find in the Western Mediterranean in the Hellenistic period is the clash of two ideologies of empire. One, dating back to the Bronze Age Near East (and paralleled elsewhere), is of universal empire. This is power without limits, conceptualized as a rimless hub and spoke system rather than a geographical area, exploiting people and their products rather than places. ${ }^{45}$ The other, a much more recent innovation, involves the careful creation and maintenance of borders. The Successor Kingdoms were to some extent exponents of the former, ${ }^{46}$ but the Seleucids in particular took great care to delineate borders to their realm, ${ }^{47}$ and in the western Mediterranean too it is kings and not cities who make territorial boundaries to their own and others' realms. While the kings of Syracuse and Numidia were demarcating their territories in the new Hellenistic fashion, however, Carthage and Rome still aimed for the kind of universal rule that Polybius identified, which we see again in the lex de repetundis, and is still a reference point in Vergil's Aeneid a century later, where the Romans are give imperium sine fine (1.279). ${ }^{48}$

\footnotetext{
${ }^{45}$ Strootman 2014.

${ }^{46}$ Strootman 2014, 46-52 on notions of universal empire among the successor kingdoms, with examples of the delineation of geographical limits to empire, if very broad ones.
}

47 Kosmin 2014, 32-37 and 59-92.

${ }^{48}$ On these Roman notions, see Nicolet 1991, 30-31 and Whittaker 1994, 32. 
It seems then that the Romans adopted a similar model of universal empire to that of Carthage, perhaps in the very period of direct confrontation between the two states. But even if Polybius is wrong, and such a notion of universal rule predated the Hannibalic War, Rome's maintenance of it along with Carthage, in the face of experimentation with other models by Hellenistic kings in east and west, cannot have been entirely unconscious or coincidental.

\section{Treaty Formulations}

The wording of treaties can take us considerably further, providing an explicit illustration of mechanisms of imperial transfer between Carthage and Rome. Those made between the two cities in the sixth and fourth centuries, and preserved by Polybius, are of Carthaginian formulation and format: not only are they quite different from the little we know of early Roman (and Greek) treaties, but Carthage is clearly the "senior" partner, overlord of far more land and sea than Rome even at the time of the fourth century treaty. ${ }^{49}$ The first begins "There is to be friendship between the Romans and their allies and the Carthaginians and their allies on these terms ( $\dot{\varepsilon} \pi \grave{i}$ $\tau o i ̃ \sigma \delta \varepsilon) "$, a formulation with near eastern roots that is used again in the fourth century treaty, at least in Polybius' translation, and reproduced in similar if more elaborate terms in the 215 treaty with Philip V of Macedon that must have been drafted in Hannibal's field chancellery. ${ }^{50}$

\footnotetext{
${ }^{49}$ Carthage's primary role in drafting the treaties: Gruen $1984,59-60$.

${ }^{50}$ Polyb. 3.22.4 (with Scardigli 1991, 56); 3.24.3; 7.9.5.
} 
According to Polybius, Rome then adopts exactly the same formulation in its own draft treaty with Carthage in 241 (Polyb. 1.62.8). It is worth emphasizing the importance of the context here: since this is a draft treaty, the Romans must be responsible for the choice of wording. Furthermore, on Appian's account, a treaty Rome made with Pinnes of Illyria in 228 established that Pinnes "would be a friend of the Roman people, if..." (App. Ill. 7): this is a report of rather than a quotation from the document, but the terms still appear very similar to those familiar from Rome's treaties with Carthage. ${ }^{51}$ Considerably later, the Roman treaty with Antiochus III in 188 is quoted by Polybius as beginning "there will be friendship for all time between Antiochus and the Roman people if he acts according to the treaty" (Polyb. 21.43.1; cf. Livy 38.38.2); the wording has evolved somewhat, but the basic promise of friendship on conditions is the same. Practices were however already changing in the late third and second centuries, as Rome built deeper diplomatic relationships in the region, established less formal friendships, and accepted treaties offered by Greekspeaking states; the influence of Greek traditions and initiatives on Roman alliances from the late third century onwards is well documented. ${ }^{52}$

\section{Taxation Policies}

Finally, it is Rome's taxation practices in the regions it took from Carthage that most vividly illustrate the transfer of imperial tactics from Carthage and from other powers. Unfortunately, all we know of Carthaginian taxation in Spain is that tax was charged

\footnotetext{
${ }^{51}$ The plausibility of this borrowing is noted at Gruen 1984, 60.

${ }^{52}$ Gruen 1984, ch. 1; Kallet-Marx 1996, 191-196.
} 
on the mines, a system which Rome certainly continued to exploit on a grand scale. ${ }^{53}$ For Sicily and Africa, however, we can say rather more.

Carthage charged taxes (phoroi) in Sicily in the fifth and fourth centuries. Diodorus tells us that after the fall of Selinus in 409 BCE, the citizens who had escaped were allowed to live in the city and work the fields on payment of a phoros to the Carthaginians (13.59.3). ${ }^{54}$ Four years later, a treaty concluded between Carthage and Syracuse includes a provision that "the Selinuntians, Acragantians, and Himerans as well as the Gelans and Camarinans may dwell in their unfortified cities, but they shall pay a phoros to the Carthaginians. ${ }^{55}$ That this phoros was thought at least by Diodorus to be a standard Carthaginian institution is suggested when he has a Syracusan citizen called Theodorus attack the city's tyrant Dionysius in 396 on the grounds that "should

${ }^{53}$ Carthaginian origins of mine taxation: Diod. Sic. 5.38.2. Roman mine taxation: Polyb. 34.9.8-9, with Richardson 1986, 120-121.

${ }^{54}$ Commentary on Carthaginian taxation in Sicily: Whittaker 1978b, 72-73; Bondì 1980, 185-6; Bondì 1990-1991, 226-8 (arguing for a uniform Carthaginian system across its territories); Hans 1983, 145-6; Gallo 1992, 394 n.53 and 397 n. 60, with a useful survey of earlier bibliography.

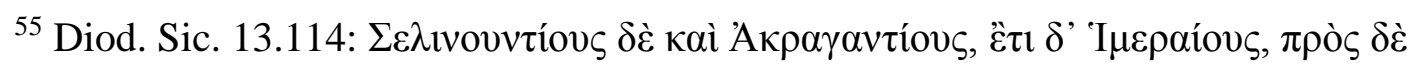

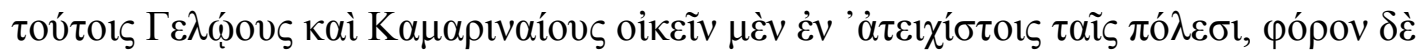

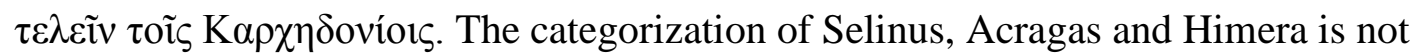
entirely clear from the text, but Diodorus has all five towns defect to Dionysius in 397, "hating as they did the heavy hand of Phoenician domination (epikrateia) and relishing at last the prospect of freedom" (14.47.5-6), suggesting that they were all placed in the same category in 405 (contra Whittaker 1978b, 72). 
the Carthaginians defeat us in war, they would impose a fixed tax (phoros horismenos), but they would not prevent us from governing the city in accordance with our ancient laws" - unlike Dionysius himself (Diod. Sic. 14.65.2).$^{56}$

The only surviving account of the initial Roman settlement of Sicily after the first Punic War in 241 comes from Appian: the greater part of the island, which had been held by the Carthaginians, passed to the Romans, who established two kinds of taxation, a phoros on the population and harbour duties (tele thalassia) on the towns. ${ }^{57}$ Livy agrees that Sicily and Sardinia were already subject to taxation (vectigales) before the Second Punic War (23.48.7; cf. Tac. Ann. 11.22). As Jonathan Prag has argued, this taxation was "one of the principal rationales for the initial

${ }^{56}$ Whittaker suggests that all this evidence is for war indemnities rather than regular tribute (1978b, 72), on the grounds that it applies "only to defeated enemies, not to allies", but that doesn't seem especially problematic. When Dionysius later pays a war indemnity of 1000 talents to Carthage, it is described in very different terms, and as a simple payment rather than a phoros: Diod. Sic. 15.17.5.

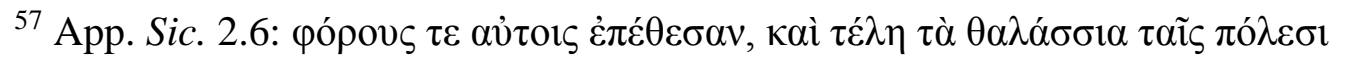

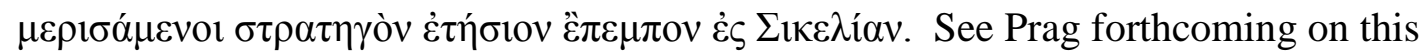
passage (numbered here according to the Teubner edition; it is 2.2 in the Loeb), including the interpretation of the tele thalassia as harbour duties, for which see also Ferrary 1988, 18-20. We don't have direct evidence for customs duties in Carthaginian Sicily, although in 195 Hannibal mentions that Carthage does collect vectigalia maritima, and these seem to be of some long standing, since they are contrasted with a more recently imposed tax on Carthaginian individuals (Livy 33.47.1-2, with 30.44.11) 
Roman presence" in Sicily; ${ }^{58}$ it was also the first taxation they levied overseas, and it seems likely that it was modelled at least in part on existing Carthaginian practice on the island. ${ }^{59}$ Appian's wording suggests that the phoros was charged on individuals, rather than on the cities, which were charged customs dues instead. ${ }^{60}$ This is in line with the little we know of earlier Carthaginian practice on the island: the tax imposed on the defeated Selinuntians in 409 was certainly a tax on individuals rather than cities, and while this may have been an unusual, ad hoc arrangement, Diodorus' wording in relation to the 405 treaty with Carthage implies again that the phoros imposed there was a tax on individuals not on cities as a whole.

There is no reason to think that either of these Carthaginian and Roman taxation systems were based on tithes; indeed, Diodorus' imaginary case of 396 specifically envisages a fixed tax. ${ }^{61}$ Our first evidence for regular tithes on grain in both Sicily and Sardinia is from the 190s, and Cicero explicitly tells us the Sicilian tithing system was based on that of Hieron II, whose kingdom fell to Rome in 215 BCE (Cic. Verr. 3.1415). ${ }^{62}$ If however Rome took over both earlier taxation strategies in Sicily, the

${ }^{58}$ Prag 2012, 61.

${ }^{59}$ A suggestion made briefly at Serrati 2000, 124-125, where it is assumed that both taxes are tithes.

${ }^{60}$ The identity of the individuals to whom Appian refers is unclear: although traditionally translated as "Sicilians", the word autois has no obvious direct reference, presumably as a result of the process of compilation in the Byzantine period.

${ }^{61}$ Prag 2012, 61, and Prag forthcoming.

${ }^{62}$ Livy 36.2.12 (Sicily, 191), 37.2.12 (Sicily and Sardinia, 190), 42.31 .8 (Sicily and Sardinia, 171). Rome had been requisitioning or otherwise receiving one-off 
Carthaginians' in 241 and Hieron's in 215, that would neatly explain Cicero's description of the first century BCE Roman arrangements on the island, where he distinguishes between ager decumanus, on which tithes were collected, and ager publicus, leased instead by the censor (Cic. Verr. $3.12-13) .{ }^{63}$ The ager publicus, he says, was the land of a "few" (perpaucae) cities defeated by Rome in war, which was then returned to them on payment of a tax, which Cicero elsewhere says was fixed (certum) by the censors (Cic. Verr. 5.53). ${ }^{64}$ There is a direct parallel in the arrangements made by Carthage for the Selinuntines in 405, and it seems most likely that this category of ager publicus finds its roots in the land taken from Carthage by Rome in $241 .{ }^{65}$ The organisation of taxation on the ager decumanus, on the other hand, should date to the systemization of Roman administration on the island in the aftermath of their acquisition of the whole island in $215 .^{66}$

payments of Sicilian and Sardinian grain from the time of the second Punic War (Livy 23.41.7 (Sardinia, 215), 27.8.19 (Sicily, 209), 30.3.2 (Sicily, 203), 33.42.8 (Sicily, 196), 36.2.12 (Sicily, 191, in addition to the regular tithe?), 37.50 .9 (Sicily and Sardinia, 189).

${ }^{63}$ This point is under-appreciated in modern scholarship: Prag 2014a, 187-189.

${ }^{64}$ See on these passages Prag 2014a, especially 192-195.

${ }^{65}$ By Cicero's time ager publicus is also found in the territory of Leontini, which had been within Hieron's kingdom (Cic. Phil. 3.22): if I am right here about the Carthaginian roots of the taxation of ager publicus on Sicily, this means that there must have been some later extension of the system.

${ }^{66}$ For a plausible theory of the Roman deployment of this taxation system throughout Sicily in the period 210-207, see Prag 2012, 60-61. 
Turning to Africa, Polybius tells us that Carthaginian public expenses were met from the revenues of Libya, and that during the first Punic war the Carthaginians demanded from the people of Libya half of their crops, and doubled the phoroi in their towns (Polyb. 1.71-72). It is of course likely that any tax would have been collected through towns and communities rather than directly from individuals, but Polybius' next comment, that no exemptions or discounts were allowed to individuals in difficult circumstances, suggests that, as in Sicily, it was individuals who were technically liable for the tax. ${ }^{67}$ We don't know whether the additional land tax on the Libyans was a permanent Carthaginian institution or an emergency measure, although the high rate, at least, must have been temporary. ${ }^{68}$ Nor do we know when either tax was instituted, although the demands of Carthage on their subjects in Libya were already sufficiently heavy in the early fourth century to provoke revolts (Diod. Sic. 14.77; 15.24.2).

According again to Appian, after Rome destroyed Carthage in 146 the arrangements they made for Africa also involved a dual taxation system, with the imposition of a phoros "both on land and on individuals, men and women alike" (App. Pun. 135). In itself this seems to reflect the earlier Carthaginian arrangements, ${ }^{69}$ and the poll tax in

\footnotetext{
${ }^{67}$ The one specific example we have of a Carthaginian tax paid by a town in Libya, the vectigal said to have been paid by the port of Lepcis in 193 of a talent a day (Livy 34.62.3), may refer to harbor dues, or to the collected taxes of a large area.

${ }^{68}$ Crouzet 2003, 683-685 on all we don't know about these arrangements.

${ }^{69}$ Richardson suggests that Rome also imposed a dual system in Spain in the second century, charging a 5\% grain levy in addition to the well-attested stipendium (1986,
} 
particular has been singled out as a potential borrowing from Carthage, simply because it is otherwise unattested $;^{70}$ the evidence discussed above for the Carthaginian preference for fixed taxes might add more support to that argument. However, the tax on land also presents a plausible parallel. It is presumably the vectigal certum that Cicero specifies was the system of land taxation imposed by Rome on "the Hispani and most of the Poeni" - that is to say here the population of North Africa - which "may be considered the reward of victory and the penalty of defeat" (Cic. Verr.

3.12). ${ }^{71}$ Although Cicero explicitly contrasts this system with that of the Sicilian ager decumanus, it may well have been similar to - or the same as - the arrangements he outlines for ager publicus in Sicily, especially since both are conceptualised as a form of punishment for defeated enemies. In both cases the notion seems to be that the vectigal is a form of fixed rent on land that has been rightfully seized by Rome, which could again in both cases reflect earlier Carthaginian arrangements, although our only direct evidence for those is the treatment of the Selinuntines in $409 .{ }^{72}$

115-116), described by Cicero as "fixed", but Rich points out that the evidence for such a levy is weak (Rich 1988, 213).

${ }^{70}$ Jones 1974, 173; Lintott 1992, 79. Poll taxes are generally considered rare until the Augustan period, although there was a royal poll tax in Hellenistic Judea (Jones 1974, $164-5,173)$.

${ }^{71}$ Land assigned to stipendarii in Africa is also mentioned in the lex agraria of 111 (11. 77, 80). See Prag 2014b on the varied meanings of Poeni in late republican Latin. ${ }^{72}$ Sandrine Crouzet tentatively discusses the possibility that the Carthaginian land tax in Africa may have been a form of rent on land owned in principle by Carthage:

Crouzet 2003, 679. 
This is perhaps the best example of the phenomenon of imperial transfer between Carthage and Rome, but I have suggested here that it is not the only one. Over the course of the third and early second century Rome reproduced, inherited, adopted or adapted a variety of Carthaginian imperial practices and ideologies, a conclusion incompatible with a fundamental distinction between these cities' imperial projects. But in even the clearer cases of imperial transfer discussed here, it arose from observation and experimentation, not blind inheritance or mimicry, and the eventual Roman solutions combined aspects of Carthaginian practice with those of other contemporary western as well as eastern imperial states. Carthage was not the only model Rome had, and it was increasingly not the model they followed. Just as Polybius suggests, Rome inherited empire from both powers in the East and the West, and its real achievement was to translate these multiple imperial models into one. ${ }^{73}$

Anello, Pietrina. 1986. Il trattato del 405/4 A.C. e la formazione della "eparchia" punica di Sicilia. Kokalos 32: 115-180.

Aust, Martin, and Daniel Schönpflug, eds. 2007. Vom Gegner lernen: Feindschaften und Kulturtransfers im Europa des 19. und 20. Jahrhunderts. Frankfurt am Main.

\footnotetext{
${ }^{73}$ I thank for advice and comments on this paper Chris Brooke, Jon Prag, Denis Feeney, and the other participants in our workshop at Princeton in September 2015. I am also grateful to Philipp von Rummel for the opportunity to try these ideas out at the Deutsches Archäologisches Institut in Berlin in June 2016.
} 
Barré, Michael L. 1983. The God-list in the treaty between Hannibal and Philip V of Macedonia: a study in light of the ancient near eastern treaty tradition. Baltimore.

Barth, Volker, and Roland Cvetkovski, eds. 2015. Imperial co-operation and transfer, 1870-1930: empires and encounters. London.

Bernal, Martin. 1987. Black Athena: the Afroasiatic roots of classical civilization. London.

Bickerman, Elias J. 1944. An oath of Hannibal. TAPA 75: 87-102.

Bickerman, Elias J. 1952. Hannibal's covenant. AJP 73.1: 1-23.

Bondì, Sandro Filippo. 1980. Le strutture politiche e amministrative della Sicilia Punica. In La Sicilia antica, ed. E. Gabba and G. Vallet, 183-187. Naples. Bondì, Sandro Fillipo. 1990-1991. L'eparchia punica in Sicilia. L'ordinamento giuridico. Kokalos 36-37: 215-231.

Bondì, Sandro Filippo. 2014. Phoenicity, punicities. In The Punic Mediterranean: identities and identification from Phoenician settlement to Roman rule, ed. Josephine Crawley Quinn and Nicholas C. Vella, 58-68. Cambridge.

Brooke, Christopher. Forthcoming. Eighteenth Century Carthage. In Commerce and Perpetual Peace, ed. Isaac Nakhimovsky, Béla Kapossy and Richard Whatmore. Cambridge.

Caven, Brian. 1990. Dionysius I: War-Lord of Sicily. New Haven.

Crawford, Michael H. 1990. Origini e sviluppi del sistema provinciale romano. In Storia di Roma. Volume II. L'impero mediterraneo. I. La repubblica imperiale, ed. by Guido Clemente, Filippo Coarelli and Emilio Gabba, 91-121. Turin. 
Crouzet, Sandrine. 2003. Les status civiques dans l'Afrique punique: de

l'historiographie moderne à l'historigraphie antique. MÉFRA 115.2: 655-703.

Di Vita-Évrard, Ginette. 1985. La Fossa Regia et les diocèses d'Afrique

proconsulaire. AfrRom 3: 31-58. Sassari.

Feeney, Denis C. 2007. Caesar's Calendar: ancient time and the beginnings of history. Berkeley.

Ferchiou, Naidé. 1998. Fossa Regia. In Encyclopédie berbère 19: 2897-2911. Aix-enProvence.

Ferguson, Adam. 1767. An essay on the history of civil society. Edinburgh.

Ferrary, Jean-Louis. 1988. Philhellénisme et impérialisme: aspects idéologiques de la conquête romaine du monde hellénistique, de la seconde guerre de Macédoine à la guerre contre Mithridate. Rome.

Gallo, Luigi. 1992. La Sicilia occidentale e l'approvvigionamento cerealicolo di Roma. AnnPisa. Classe di lettere e filosofia 22: 365-398.

Grey, Anchitell. 1763. Debates of the House of Commons from the year 1667 to the year 1694. London.

Gruen, Erich S. 1984. The Hellenistic World and the Coming of Rome. Berkeley.

Hans, Linda-Marie. 1983. Karthago und Sizilien: die Entstehung und Gestaltung der Epikratie auf dem Hintergrund der Beziehungen der Karthager zu den Griechen und den nichtgriechischen Völkern Siziliens (VI.-III. Jahrhundert v. Chr.), Historische Texte und Studien. Hildesheim and New York.

Hart, Jonathan L. 2008. Empires and colonies. Cambridge.

Janni, Pietro. 1984. La mappa e il periplo: cartografia antica e spazio odologico. Rome. 
Jones, A. H. M. 1974. The Roman economy: studies in ancient economic and administrative history. Ed. Peter A. Brunt. Oxford.

Kallet-Marx, Robert. 1996. Hegemony to Empire: the development of the Roman Imperium in the East from 148 to 62 B.C. Berkeley.

Kent, Patrick. 2012. Reconsidering Socii in Roman Armies before the Punic Wars. In Processes of integration and identity formation in the Roman Republic, ed. Saskia Roselaar, 71-83. Leiden.

Kosmin, Paul J. 2014. The land of the elephant kings: space, territory, and ideology in the Seleucid Empire. Cambridge, Mass.

Lancel, Serge. 1995. Carthage: a history. Oxford.

Leonhard, Jörn, and Ulrike von Hirschhausen, eds. 2011. Comparing empires: encounters and transfers in the long nineteenth century. Göttingen.

Lintott, A. W. 1992. Judicial reform and land reform in the Roman Republic: a new edition, with translation and commentary, of the laws from Urbino. Cambridge.

Mazzarino, Santo. 1947. Introduzione alle guerre puniche. Catania.

Miles, Richard. 2010. Carthage must be destroyed: the rise and fall of an ancient Mediterranean civilization. London.

Milton, John. 2013. The Complete Works of John Milton. Volume VI: Vernacular Regicide and Republican Writings. Oxford.

Montagu, Edward Wortley. 1759. Reflections on the rise and fall of the antient republicks Adapted to the present state of Great Britain. London.

Montesquieu, Charles de Secondat. 1777. The complete works of M. de Montesquieu. Translated from the French. London: T. Evans and W. Davis. 
Moscati, Sabatino. 1972. I Fenici e Cartagine, Società e costume: panorama di storia sociale e tecnologica. Turin.

Nicolet, Claude. 1991. Space, Geography and Politics in the Early Roman Empire. Ann Arbor.

Palmer, Robert. 1997. Rome and Carthage at Peace. Stuttgart.

Prag, Jonathan R. W. 2011a. Provincial governors and auxiliary soldiers. In Les gouverneurs et les provinciaux sous la République romaine, ed. Nathalie Barrandon and François Kirbihler, 15-28. Rennes.

Prag, Jonathan R. W. 2011b. Troops and commanders: auxilia externa under the Roman Republic. In Truppe e Comandanti nel mondo antico (= HORMOS n.s. 2, 2010), ed. Daniela Bonanno, Rosalia Marino and Daniela Motta, 101-113. Palermo.

Prag, Jonathan R. W. 2012. Sicily and Sardinia-Corsica: the first provinces. In A Companion to Roman Imperialism, ed. Dexter Hoyos, 53-65. Leiden.

Prag, Jonathan R. W. 2014a. Cities and civic life in late Hellenistic Roman Sicily. Cahiers du Centre Gustave Glotz 25: 165-208.

Prag, Jonathan R. W. 2014b. Phoinix and Poenus: usage in antiquity. In The Punic Mediterranean: Identities and Identification from Phoenician settlement to Roman rule, ed. Josephine Crawley Quinn and Nicholas C. Vella, 11-23. Cambridge.

Prag, Jonathan R. W. Forthcoming. $\tau \dot{\varepsilon} \lambda \eta \tau \grave{\alpha} \theta \alpha \lambda \alpha ́ \sigma \sigma 1 \alpha$ in Appian Sik. 2.6 and Roman taxation in Sicily between the Punic Wars.

Purcell, Nicholas. 1990. Maps, Lists, Money, Order and Power. JRS 80:178-182.

Purves, Alex C. 2010. Space and time in ancient Greek narrative. Cambridge. 
Quinn, Josephine Crawley. 2004. The Role of the Settlement of 146 in the Provincialization of Africa. AfrRom 15: 1593-1601.

Quinn, Josephine Crawley. 2012/2013 [2014]. Tophets in the "Punic World". In The "Tophet” in the Phoenician Mediterranean (= Studi Epigrafici e Linguistici 29-30), ed. Paolo Xella, 23-48. Verona.

Quinn, Josephine Crawley. 2014. A Carthaginian Perspective on the Altars of the Philaeni. In The Punic Mediterranean: identities and identification from Phoenician settlement to Roman rule, ed. Josephine Crawley Quinn and Nicholas C. Vella, 169-179.

Quinn, Josephine Crawley. Forthcoming. In Search of the Phoenicians. Princeton.

Rawlinson, George. 1889. History of Phoenicia. London and New York.

Rich, John W. 1988. Review of J. Richardson, Hispaniae: Spain and the development of Roman imperialism, 218-82 BC (1986). JRS 78: 212-214.

Richardson, John. 1986. Hispaniae: Spain and the development of Roman imperialism, 218-82 BC. Cambridge.

Richardson, John. 2008. The language of empire: Rome and the idea of empire from the third century $B C$ to the second century $A D$. Cambridge.

Schmidt, H. D. 1953. The Idea and Slogan of "Perfidious Albion”. Journal of the History of Ideas 14.4: 604-616.

Serrati, John. 2000. Garrisons and grain: Sicily between the Punic Wars. In Sicily from Aeneas to Augustus, ed. by Christopher J. Smith and John Serrati, 11533. Edinburgh.

Steinby, Christa. 2014. Rome versus Carthage: the war at sea. Barnsley. 
Strootman, Rolf. 2014. Hellenistic imperialism and the idea of world unity. In The City in the Classical and Post Classical World: changing contexts of power and identity, ed. Claudia Rapp and H. A. Drake, 38-61. Cambridge.

Stylianou, P. J. 1998. A historical commentary on Diodorus Siculus, book 15. Oxford. Thonemann, Peter. 2015. The Hellenistic world: using coins as sources. Cambridge. Vance, Norman. 2000. Imperial Rome and Britain's Language of Empire 1600-1837. History of European Ideas 26.3-4: 211-224.

Vincenzo, Salvatore De. 2013. Tra Cartagine e Roma: i centri urbani dell'eparchia punica di Sicilia tra VI e I sec. a.C. Berlin.

Vlassopoulos, Kostas. 2010. Imperial Encounters: discourses on empire and the uses of ancient history during the eighteenth century. In Classics and Imperialism in the British Empire, ed. Mark Bradley, 29-53. Oxford.

Walsh, Joseph J. 1996. Flamininus and the Propaganda of Liberation. Historia 45: 344-363.

Walsh, P. G. 1965. Massinissa. JRS 55: 149-160.

Whittaker, C. Richard. 1978a. Land and Labour in North Africa. Klio 60: 331-362.

Whittaker, C. Richard. 1978b. Carthaginian Imperialism in the 5th and 4th Centuries. In Imperialism in the Ancient World, ed. by Peter Garnsey and C. Richard Whittaker, 58-90. Cambridge.

Whittaker, C. Richard. 1994. Frontiers of the Roman Empire. Baltimore.

Whittaker, C. Richard. 2004. Rome and its Frontiers: the dynamics of empire. London. 